\title{
エンコーダの光学と集積化
}

\author{
正 員 羽根 一博*
}

\section{Optics for Encoders and Integration}

\author{
Kazuhiro Hane*, Member
}

Optics for encoders is studied from the point of view of signal improvement and miniaturization. Basis of optical encoder is the superposition of two gratings. Moire encoder consisting of two superimposed gratings is simple but the encoder signal is often affected by the variation of air gap due to the Fourier image effect. In this paper, basic optics of the encoders is summarized and some advanced optics for the Moire encoders are explained to suppress the influence.

キーワード : 光エンコーダ, 回折格子, 光集積化

Keywords : Optical encoder, Diffraction grating, Optical integration

\section{1. はじめに}

光学式エンコーダ（光エンコーダ） はメカトロニクス機 器の位置や角度の検出に欠かせないセンサである。近年, メカトロニクス機器の高精度化に伴い, エンコーダを装着 して高度な制御することが望まれるようになった。これに 伴い，小型で性能の高い光エンコーダの開発が望まれてい る。エンコーダに対する要求としては（1）小型である, （2）分解能が高い,（3）取り付けの許容範囲が広い, （4）ゼロ点検出ができる，（5）できればアブソルート方 式（相対位置でなく絶対位置が検出できる）などが挙げら れる。この中で, センサの小型化にはマイクロマシニング 技術が有効である。光源やインデックス格子，光検出器な どを一体に集積できる。

最も基本的なエンコーダ（モアレ型）の構成を図 1 に示 す。光源，メインスケール (スケール格子)，インデックス スケール (インデックス格子), 光検出器で構成される。光 源には発光ダイオード（LED）が用いられるが，高分解能の ものにはレーザが用いられる。2 枚の格子を重ねあわせるモ アレ式のエンコーダは部品の数が少ないことや，部品の光 学配置が簡単であることから広く利用されている。

高分解能であるためには，スケール格子の周期は小さい 方がよい。スケールの周期が小さくなり波長に近くなると， 光の回折の効果が顕著になる。このため，スケール格子か らインデックス格子が離れるに従い，格子像のコントラス トが低下して，エンコーダ信号として利用できなくなる。 レーザ光を用いるとコヒーレンスがよいので，信号の劣化

\footnotetext{
東北大学大学院工学研究科ナノメカニクス専攻

干980-8579 仙台市青葉区荒巻字青葉 6-6-01

Dept. of Nanomechanics, Tohoku University
}

Aza Aoba 6-6-01, Aramaki, Aoba-ku, Sendai 980-8579

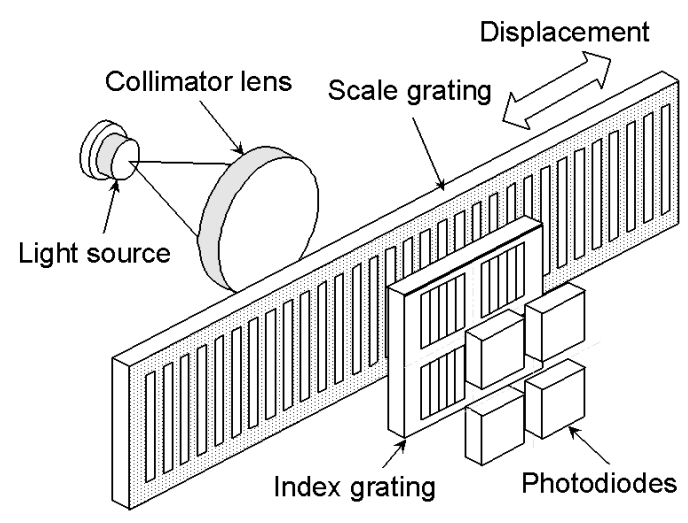

図 1 モアレ型エンコーダの基本構成

Fig. 1. Basic structure of Moire-type encoder

は幾分抑えられるが, 回折光の干渉効果（フーリエイメー ジ(1) により, 間隙の変化で信号コントラストおよび位相が 変動する。

本研究では，光エンコーダにおいて，上に述べたような 問題や限界が発生する理由を光学の基本から説明し, それ らの解決法の研究について紹介する。特にモアレ型エンコ ーダの信号が間隙変化の影響を受けないようにするための 方式について紹介する。具体的には, 変調位相格子, 指向 性光検出器, 格子イメージングなどである。それらのエン コーダの集積化についても触れる。

\section{2. 光エンコーダの基本光学系}

光エンコーダの光学の基本について説明する。図 2 に基 本的な 3 つ光学系を示した。図 2(a)は干渉型エンコーダの 光学系, (b)はモアレ型の光学系, (c)は格子イメージ型の光 学系である。 
干渉型エンコーダの光学系は最も簡単である。2つのレー ザビームを特定の角度で重ね合わせる。ビームが重なった 領域には, 空間干渉縞が発生する。2つのビームの交差角を $2 \theta$ として，空間干渉縞の周期を $p$ とすると，

$$
p=\frac{\lambda}{2} \frac{1}{\sin \frac{\theta}{2}} \text {. }
$$

により与えられる。ここで， $\lambda$ は波長である。 $\theta$ が大きくな ると $p$ は小さくできるので, エンコーダの分解能が向上す るが, 半波長が最小值となる。

二光束干渉の場合, 空間干渉縞の強度分布は単一の正弦 波で表現できる。図 2(a)に示す位置に格子を置くとき，交差 領域の中であれば，その位置によらず，格子の前面には強 度分布が単一正弦波で表される空間格子が形成されてい る。格子（周期 $p$ ） はインデックス格子であってもスケール 格子であっても良い。また，光検出の方法として，格子の すぐ後ろの位置に光検出器を置く方法, あるいは格子から の回折光を重ねあわせる方法でも，得られるエンコーダ信 号は理論的に単一正弦波となる。また，格子の位置が光軸 （z 軸）方向に移動しても, 空間格子の分布がほとんど変わ らないので，信号コントラストに変化は生じない。空間格 子の周期を波長と同程度に小さくできること及び理想的な 正弦波信号が得られやすいことから，エンコーダとしては 理想的な光学系となる。交差する 2 つのビームを発生させ るため, レーザ光源の光を分離, 重ねあわせる必要があり, 光学部品の配置が幾分複雑になる。また, レーザ光を分離 してから, 重ね合わせるまでの距離が長いと, 空閒の摇ら ぎの影響を受けやすい。マイクロマシニングにより製作す ると小型で安定なエンコーダとなる(2)。

図 2(b)のモアレ型エンコーダの光学系においては 2 枚の 格子 (周期 $P$ ) を重祆合わせる。光学系は極めて単純であり, 2 枚の格子を通り抜けた光量を検出する。格子の周期が大き いときは，回折の効果は少なく，スケール格子のスリット の影がインデックス格子の上に重なるだけであるので，ス リットが矩形透過率分布を持つ場合は，信号は単純な三角 波形（格子のデューティ比が 0.5 の場合）となる。

しかし, 高い分解能を実現するため格子の周期を小さく すると，入射光の回折が生じて，スケール格子を透過した 光束は広がる（いくつかの次数の回折光に分離される）。レ 一ザ光を入射させる場合, スケール格子後ろの領域の光の 空間分布は角度スペクトルに分解した平面波の重ね合わせ で近似できる。すなわち，回折格子から遠方で，明確に分 離された各次数の回折光ビームになる光波（平面波）をス ケール格子の後ろの領域で重ね合わせたときに得られる空 間干渉縞で近似できる。この領域は，図 2(b)では三角の交差 領域として示されている。もし，0次光がない場合は図 2(a) に示したひし形の空間干渉領域の右半分領域と同等と考え ることができる。従って，スケール格子から \pm 1 次光しか発 生しなければ, 格子の後ろの空間干渉縞は図 2(a)の場合と同 じになり，インデックス格子を置いたとき，エンコーダと
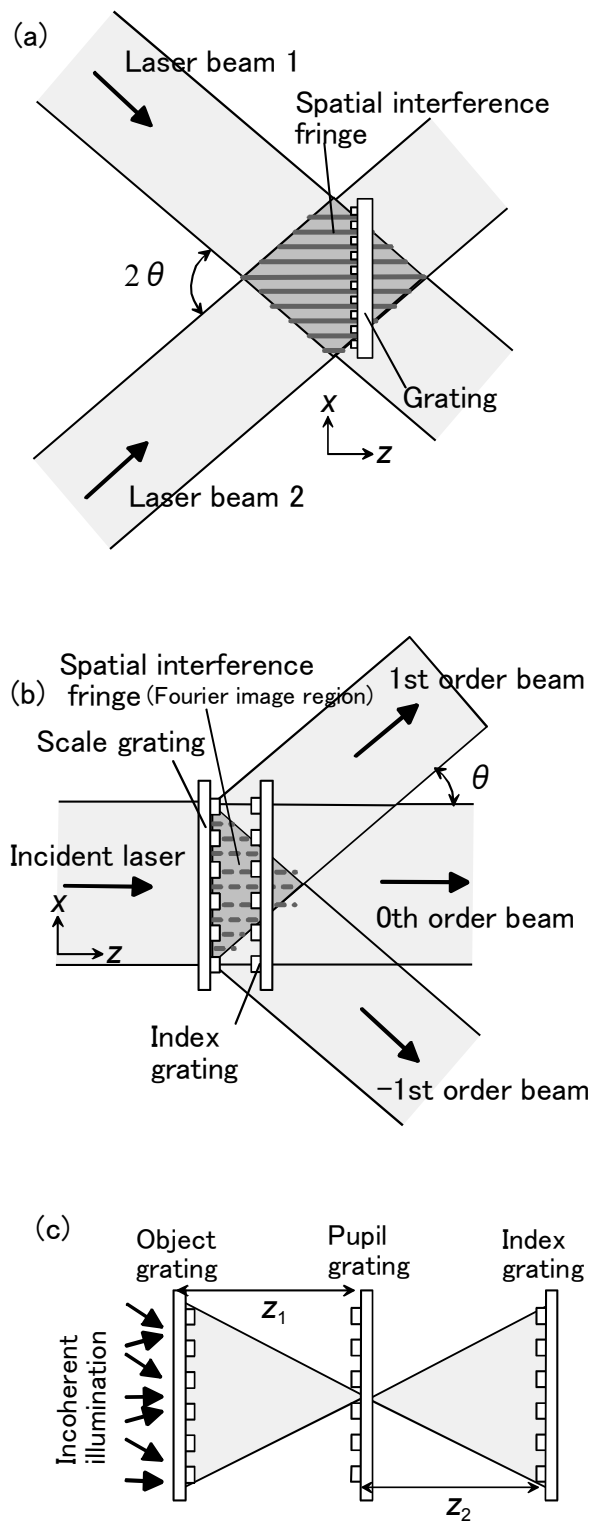

図 2 光エンコーダの基本的な光学系
(a) 干渉型エンコーダ,
(b) モアレ型エンコーダ,

(c) 格子イメージ型エンコーダ

Fig. 2. Basic optics in optical encoders, (a) Interferometric encoder, (b) Moire encoder, (c) Grating image encoder

して理想的な信号が得られる。

単一周期の格子では, 位相格子を用いると 0 次回折光消 滅条件が得られることはよく知られている。（3,5 次などの 奇数の高次光が発生するので, この場合も \pm 1 次光のみの干 渉による理想的な空間干渉縞は得られない）数学的には, 回折光各次数の光波の振幅比は, 格子の振幅透過率のフー リ工級数展開の係数比で与えられる。従って, \pm 1 次回折光 のみを発生させることができる透過率分布を持った回折格 子を実現することができないことが分かる。このため, ス ケール格子の後方にできる空間干渉縞の領域（フレネル領 域）では, 3 光束以上の多光束干渉による空間干渉縞が発生 する。一般的に用いられるクロムマスクのような振幅格子 
において, 0 次光は必ず発生するので, 強度の強い 0 次光と \pm 1 次光の 3 光束干渉が主要になる。 \pm 1 次光の干渉では図 2(a)に示す単一正弦波分布が得られるが，0 次光が存在する と, 3 光束干渉となり, 空間干渉縞は光軸方向（ $\mathrm{z}$ 方向）に も強度が変調される。光軸方向の強度分布の周期 $Z p$ は

$$
Z p=\frac{2 P^{2}}{\lambda}
$$

で与えられる。 $Z p$ はフーリエイメージ（あるいはフレネル イメージ(3), セルフイメージ) 距離と呼ばれる。すなわちス ケール格子透過直後の光強度分布が, 図 2(b)の三角の空間干 渉領域内で $Z p$ 整数倍の距離のところに再現される。（半整 数倍の位置にも同様の光強度分布が得られるが, $P / 2$ だけ横 に変位している。）ここで，図 2(a)の空間干渉縞の周期 $p$ は 図 2(b)の空間干渉縞の（光軸に垂直方向, $\mathrm{x}$ 方向）周期 $P$ の 半分であることに注意が必要である。

フーリエイメージの発生する距離にインデックス格子を 設置すれば，インデックス格子のスリットを透過する光の 強度はコントラストが高くなり, エンコーダとして優れた 信号が得られる。Talbot干渉(4)を利用するエンコーダはこの 現象を利用している。しかし，リニアエンコーダのように 格子間隙の変化しやすいエンコーダにおいては，間隙の変 化で，信号コントラストが大きく変動し，場合によっては, 信号位相が反転する。図 3 にエンコーダ信号の計算例を示 した。また，格子周期 $P$ を小さくすると $Z p$ は 2 乗で減少す るので, 高い分解能のために小さい格子を用いると, 格子 間隙を極めて小さい範囲に設定する必要がある。たとえば $P$ $=1 \mu \mathrm{m}$ で $\lambda$ が $0.5 \mu \mathrm{m}$ のとき, $Z p$ は $4 \mu \mathrm{m}$ となる。従って, 実用上，利用可能な格子周期は制限される。このように， モアレ型エンコーダでは, 0 次回折光（あるいは 2 次以上の 高次回折光）の発生が理想的な単一正弦波のエンコーダ信 号を取り出すための障害となっている。

モアレ型エンコーダは安価であることが魅力であるの で，レーザを光源に用いることは少ない。LED を光源に用

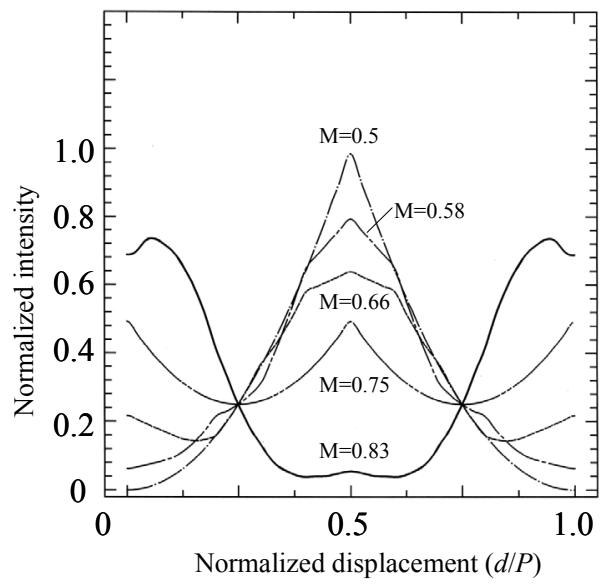

図 3 モアレ型エンコーダの信号波形（理論）

（格子間隙は $\mathrm{MZp}$ )

Fig. 3. Signal waveform of Moire encoder (Theory) (Air gap between the gratings is $M Z p$ )
いると，光源が空間的にインコヒーレントであるため，図 2(b)に示されたようなスケール格子の後ろに形成されるフ ーリエイメージの三角領域はほとんど形成されず，格子裏 面から $Z p$ 程度の距離において信号コントラストは低下して しまう。このため，格子の周期が小さいと，極めて狭い格 子間隙を保つ機構が必要である。従って, 現実的には数 $\mu \mathrm{m}$ の周期が限界となる。

インコヒーレント光源であっても，比較的大きな間隙に おいて高いコントラストのエンコーダ信号が得られる光学 系が存在する。図 2(c)に示す 3 枚格子を間隙 $z_{1}, z_{2}$ を空けて 配置した光学系を考える。物体格子が空間的にインコヒー レントに照明されているとき，第 2 格子（瞳格子）により 回折された光が, 重ね合わせられ, $z_{2}$ の位置に格子像を形成 する。第 2 の格子があたかもレンズのように作用して，格 子像を第 2 の格子の後方に形成する。方向の揃わないイン コヒーレントな光はいろいろな方向に進む平面波の重祆合 わせで近似できるが，特定の格子周期と間隙の条件により， 回折効果により格子状の像が形成でき, 格子イメージング 現象として知られている ${ }^{(5)}$ (8)。格子像のできる位置にイン デックス格子を置いて, エンコーダを構成できる。実際に エンコーダとして利用する場合は，第 2 の格子を反射格子 とする。このとき図 2(c)に示した 3 枚格子の光学系は間隙 $z_{1}=z_{2}$ の条件となり, 2 枚の格子で構成できる。 $z_{1}=z_{2}$ の条 件でコントラストの高い格子像が形成できる格子周期の比 は3つの格子に対して 2:1:2 あるいは 1:1:1である。 後者の周期比の条件では, 間隙の変化により格子像のコン トラストが反転しないので, 波長帯域の拡がった光源を用 いると，間隙の変化によらずエンコーダ信号が測定ができ る。前者の場合は後者よりコントラストが高いが, 間隙に よってはコントラストが反転する。しかしながら, モアレ 型のエンコーダに比較して, インコヒーレント光源で, 広 い間隙で動作できるので，有効である。

\section{3. モアレ型エンコーダの改良}

〈3·1〉変調位相格子、ーザ光を用いた場合, 間隙 変化に対して信号コントラストが周期的に変化する現象の 本質は, 回折光の 0 次と \pm 1 次光（あるいは高次光）が相互 に干渉することによる。もし 1 次光のみが発生できるよう な回折格子を実現できるならば, 信号コントラストの $\mathrm{z}$ 軸方 向に対する周期的変化をなくすことができる。

0 次回折光消滅条件の位相格子において周期を変調して, 等価的に, 高次 (3 次, 5 次. . ) 回折光の影響を打ち消寸こ とができることが見出された ${ }^{(9)}$ 。図 4 に周期変調位相格子の 形状を示す。位相差は位相格子の厚さにより決められるが， 格子深さに相当する位相差を 0 次光が消滅する条件である $\pi / 2$ に設定する。各回折光の成分の割合は, 格子の透過率 (位 相格子の場合は複素数) のフーリエ係数に比例する。格子 の周期を部分的にシフトさせることで, 格子周期に変調を 加えて, 図 4 に示寸ような 3 次と 5 次のフーリエ係数が消 滅する回折格子を設計，製作した。これにより 3 次と 5 次 


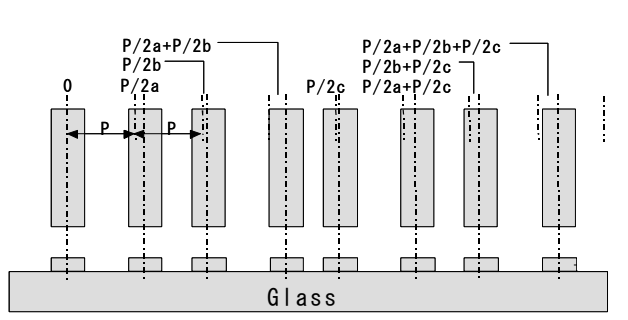

図 4 周期変調位相格子の形状 ( $\mathrm{P}$ : 周期, a,b,c : 変調量)

Fig. 4. Profile of pitch-modulated phase grating (P:period, $\mathrm{a}, \mathrm{b}, \mathrm{c}$ : modulation values)

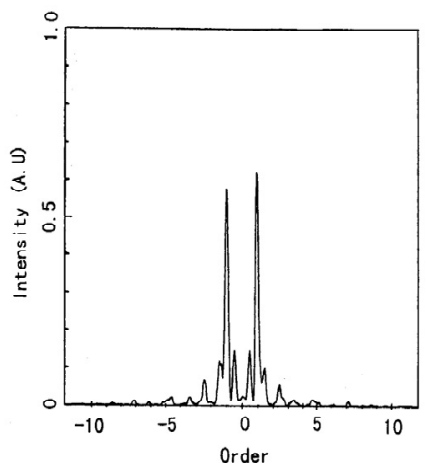

図 5 周期変調位相格子からの回折光 ${ }^{(9)}$

Fig. 5. Diffraction light from pitch-modulated phase grating
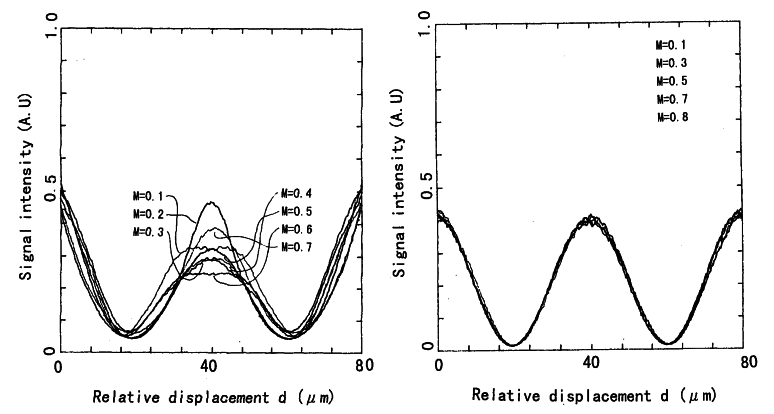

図 6 エンコーダ信号の間隙による変化 ${ }^{(9)}$

(左 : 周期変調していない場合, 右 : 周期変調した位相格 子，格子間隙は $M Z p$ である)

Fig. 6. Variation of encoder signals with airgap as a parameter (left: without pitch modulatin, right: with modulation, airgap is equal to $M Z p$ )

の回折光が生じない。さらに高次の回折光成分を打ち消す には, さらに高次の変調を加える必要がある。偶数次の回 折光は，格子形状の対称性からもともと発生しない。

得られた回折光を図 5 に示す。 \pm 1 次光が顕著に発生し, 3 次, 5 次光は発生していないことが分かる。（ただし整数 でない中間的な次数に弱い回折光が発生する）また信号波 形を図 6 に示す。エンコーダ信号は，変調位相格子を用い た場合，信号は間隙変化の影響をほとんど受けない。

〈3・2〉指向性光検出 モアレ型エンコーダ信号の間 隙依存性を改善する方法として光検出器（フォトダイオー ド：PD）の感度に指向性を持たせた方式を提案してい

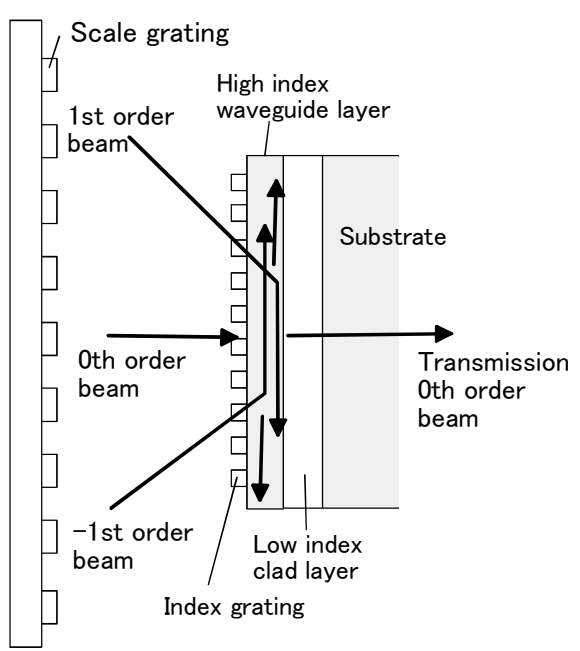

図 $7 \pm 1$ 次光の方向に指向性を持つフォトダイオードを 用いたエンコーダ

Fig. 7. Encoder with a photodiode having the directional sensitivity along $\pm 1^{\text {st }}$ order beams

る ${ }^{(10)(11)}$ 。PD は表面のフレネル反射による指向性を持つの で, 垂直方向に感度が高い。もし, 特定の方向, すなわち \pm 1 次回折光の方向からの光のみ検出できるような指向性 を備えた PDを実現できれば, モアレ型エンコーダの信号を 改善できると考えられる。

PD に指向性を持たせるために, グレーティングカプラの 構造に注目して, 設計と理論的検討を行った。図 7 に構造 を示す。SOI ウエ八を用い，上層のシリコンに PD を形成す る。シリコンの屈折率は 3.7 と高いので, 導波路のコアとし て動作する。格子に入射した 1 次回折光は導波路のモード と結合する。格子と導波路の構造により, ブラッグ格子（2 次モード) のように動作する。漏れモードであるので, 導 波してから再び外部へ放射するが，構造を最適化すること で, シリコン層で多重反射を繰り返しながらシリコンに吸 収される割合を最大化できる。シリコンの不純物濃度と波 長により光の吸収長は変化するが, 本研究の条件では約 15 $\mu \mathrm{m}$ である。導波路の屈折率が高いので, 厚さはサブミク ロンとなる。電磁界解析の厳密解法により, 最適条件を求 めると，インデックス格子（グレーティングカプラ）周期 は $670 \mathrm{~nm}, \mathrm{SOI}$ シリコン上層の厚さは $380 \mathrm{~nm}$, スケール格子 の周期はインデクス格子の周期の 2 倍である。インデック ス格子は $\mathrm{HfO}_{2}$ を用い, 厚さは $220 \mathrm{~nm}$ であり, $\mathrm{SiO}_{2}$ 層の厚さ は $1.0 \mu \mathrm{m}$ である。

図 8 に光センサとして形成した薄膜のPD の構造と製作し たセンサの断面構造を示す(11)。PD は薄いシリコン層 （380nm）であるので, 横方向の格子状の接合を周期 $20 \mu \mathrm{m}$ で製作した。

図 9 にセンサの指向性感度とエンコーダの信号波形の測 定結果を示す ${ }^{(12)}$ 。指向性は 35 度方向に強い感度を持つこと が分かる。1 次光と 0 次光に対する感度の比は 3.3 である。 理論計算によると, この比は 27 であり, 1 次回折のシリコ 


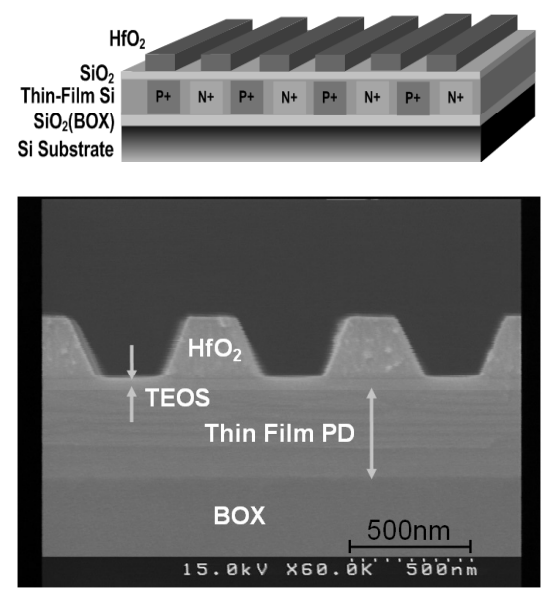

図 8 インデックス格子と光センサ部の構造と製作結果 ${ }^{(12)}$ Fig. 8. Structures of index grating and sensor part and the fabricated device
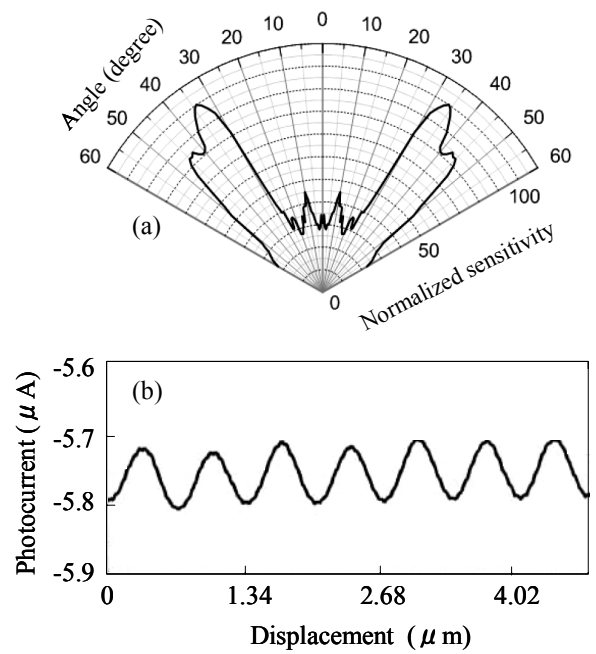

図 9 (a) センサの指向性, (b) エンコーダ信号

Fig. 9. (a) Directionality of the sensor, (b) Encoder signal

ン層での吸収割合は $80 \%$ が得られている。このように 0 次 回折光に感度が低く, \pm 1 次回折光に対して感度の高い光セ ンサが実現できた。図 9 に示されたエンコーダ信号の波形 は正弦波に近く，間隙を変えても，ほとんど信号コントラ ストは変化しなかった。

\section{3. 格子イメージ型エンコーダ}

図 10 に格子イメージを用いたエンコーダの構造を示 す(13) (15)。反射型スケール格子とセンサ部で構成される。セ ンサ部はシリコンの微細加工により製作されている。格子 イメージを用いたエンコーダでは，3枚の格子を用いる。光 源（LED）から出たインコヒーレントな光は物体格子を通る ことで，格子状の発光パターンとなる。第 2 の格子はスケ 一ル格子で回折により物体格子の像を特定の条件で結像す る働きがある。スケール格子が反射格子であるので，照射 光が反射され, 格子像がセンサ部の物体格子面上に形成さ

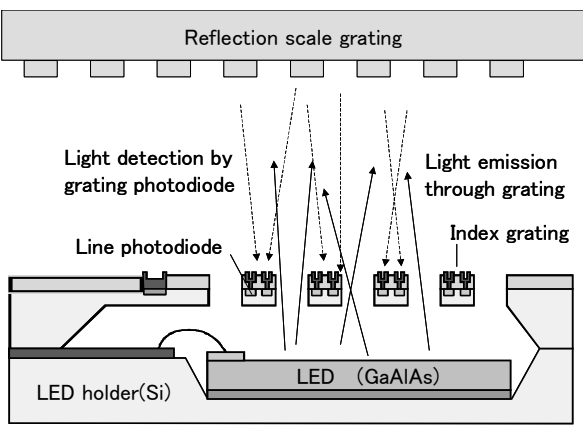

図 10 格子イメージを用いた集積型エンコーダ

Fig. 10. Integrated encoder based on grating imaging

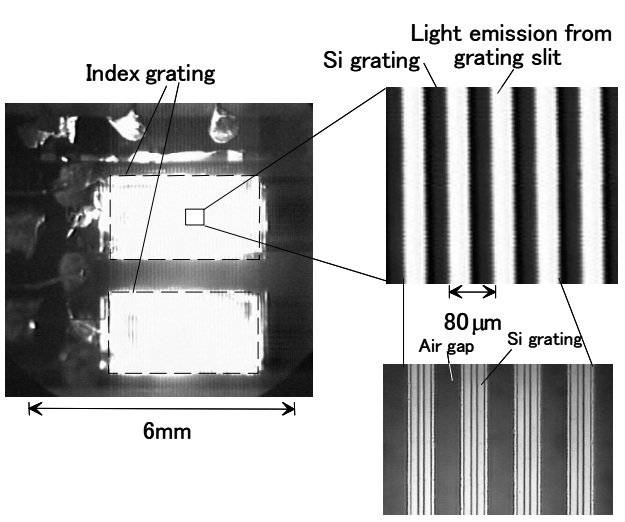

図 11 製作した格子イメージ型エンコーダ

Fig. 11. Fabricated grating-image encoder

れる。従って, 光が出射する物体格子の面に縞状の光強度 分布が形成される。図 10 に示すように, 物体格子をシリコ ンの貫通エッチングにより形成し，格子のスリット部分を 通して光を放出する。スケール格子で反射して戻って来た 光は物体格子の上に形成された PDにより測定する。従って 物体格子は格子状の光源として働き，また同時に格子状の 像の強度を測定する光検出器して動作する。センサ部の集 積化においては，格子をシリコンの深掘りエッチングによ り形成した。光源は GaAs の面状の LED をシリコン格子の 後ろに配置した。LED に配線を接続し, 固定するためのホ ルダーもシリコンで製作し，その後ろに信号処理用 IC を取 り付けた。IC は一番上の格子面に格子と隣り合わせに製作 することもできる。

図 11 は製作したセンサ部の写真である。シリコン基板を 貫通エッチングして格子を製作した。格子周期は $80 \mu \mathrm{m}$ で ある。発光時の写真であるが, 格子の裏面から放射された 光が，格子の隙間を通り放射されている。また非発光時の 格子部の光学顕微鏡写真も示されているが，シリコンの自 立格子上に線上の PD が形成されている。格子の拡大写真に はシリコンの格子 1 本に 2 本の線状 PD が形成されている。 このエンコーダにより, 周期 $40 \mu \mathrm{m}$ の正弦波信号が得られ た。信号コントラストはおよそ $20 \mathrm{~mm}$ まで間隙を広げても ほぼ一定であった。

図 12 に格子イメージを用いた集積型エンコーダにより得 


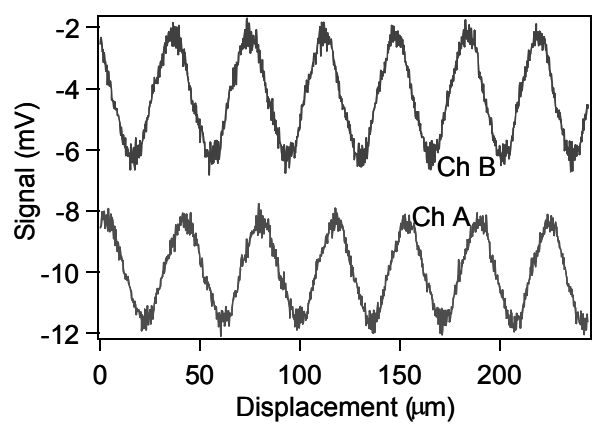

図 12 格子イメージ型エンコーダの信号

Fig. 12. Encoder signal of grating-image encoder

られた信号の例を示す。位相が 90 度ずれた 2 チャンネルの 信号が得られている。光源も自作のため, 幾分ノイズが多 いが，格子イメージ型のコンパクトなエンコーダが実現で きた。格子周期はPD を格子上に形成しているためあまり小 さくできないが，PDを別にすれば，小さい周期格子も利用 できる。

\section{4. まとめ}

モアレ型エンコーダの光学系において, 空間に生じる干 渉縞とエンコーダ信号の関係を説明した。0 次回折光の干渉 効果ために, 格子の間隙の方向に空間干渉縞が変調され, 信号波形がひずむ。この影響を取り除くため，変調周期の 位相格子，指向性のある光検出器を提案した。また，間隙 が広くとれる格子イメージ型の集積型エンコーダを紹介し た。モアレ型の光エンコーダは簡単な光学系であるが，背 後の光学は意外に複雑である。今後のマイクロエンコーダ の開発の参考になれば幸いである。

\section{謝 辞}

本解説は佐々木実氏，金森義明氏，家城淳氏，崔峯碩氏 らと行った研究の成果をまとめたもので，各氏に感謝いた します。

(平成 19 年 5 月 14 日受付)

\section{文献}

(1) J. M. Cowley and A. F. Moodie : "Fourier images:I the point source", Proc.Phys Soc (London), Vol.70, pp.486-496 (1957)
(2) R. Sawada, E. Higurashi, T. Ito, O. Ohguchi, and M. Tsubamoto : "Monolithic-integrated microlaser encoder", Appl.Opt., Vol.38, No.33, pp.6866-6873 (1999)

( 3 ) J. T. Wintherop and C. R. Worthington : "Theory of Fresnel images. I. Plane periodic object in monochromatic light”, J.Opt.Soc.Am., Vol.55, pp.373-382 (1965)

(4) P. Szwaykowski and V. Arrizon : "Talbot array illuminator with multilevel phase gratings", Appl.Opt., Vol.32, No.7, pp.1109-1114 (1993)

(5) P. M. Pettegrew : "Analysis of grating imaging and its application to displacement metrology”, SPIE, Proc., Vol.136, pp.325-332 (1977)

(6) G. J. Swanson and E. N. Leith : "Analysis of Lau effect and generalized grating imaging”, J.Opt.Soc.Am, A Vol.2, No.6, pp.789-793 (1985)

( 7 ) K. Hane and C. P. Grover : "Imaging with rectangular transmission gratings", J.Opt.Soc.Am, A Vol.4, No.4, pp.706-711 (1987)

(8) K. Hane and C. P. Grover : "Magnified grating images used in displacement sensing", Appl.Opt., Vol.26, No.12, pp.2355-2359 (1987)

(9) A. Ieki, K. Matusi, M. Nashiki, and K. Hane : "Pitch-modulated phase grating and its application to displacement encoder", J.Mod.Opt., Vol.47, No.7, pp.1213-1225 (2000)

(10) B. Choi, Y. Kanamori, and K. Hane : "Design and fabrication of a thin film silicon photodetector with angular sensitivity for optical micro-encoder”, 電学論 E, 127, pp.309-313 (2007)

(11) B. Choi, Y. Kanamori, and K. Hane : "A phase sensitive photodiode based on guided resonant absorption", Appl.Phys.Lett., Vol.90, pp.241114-1-3 (2007)

(12) B. Choi, Y. Kanamori, and K. Hane : A displacement encoder sensor based on directional thin-film resonant photodetector", Transducers 2007, pp.2357-2360 (2007)

(13) K. Hane, T. Endo, Y. Ito, and M. Sasaki : "A compact optical encoder with micromachined photodetector”, J.Opt. A:Pure Appl.Opt., Vol.3, No.3, pp.191-195 (2001)

(14) K. Hane, T. Endo, M. Ishimori, I. Ito, and M. Sasaki : "Integration of grating-image-type encoder using $\mathrm{Si}$ micromachining", Sensors \& Actuators A, Vol.97-98, No.1, pp139-146 (2002)

(15) Y. Kanamori, R. Kamata, M. Mitamura, Y. Ito, and K. Hane : "Modified photo-sensors for grating-image type micro-encoder", Microsyst.Technol., Vol.11, No.8-10, pp.980-986 (2005)

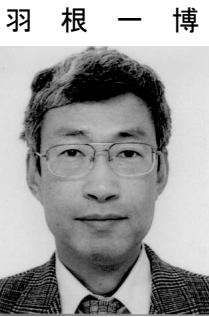

（正員） 1955 年 6 月 28 日生。1978 年名古屋 大学工学部電子工学科卒業。1980 年同大修士課 程修了。1983 同大博士課程修了。同年同大助手。 1985 年 2 月から 13 ケ月カナダ国立研究所物理 (光学) 部門研究員。1990 年名古屋大学助教授。 1994 年東北大学教授。現在に至る。メカトロニ クスへの光技術の応用, 微細加工による光セン サ・光部品の開発，光計測等の研究に従事。機 械学会, 応用物理学会, 日本光学会, レーザ学会, 精密工学会会員。 